\section{A case study of runoff and sediment yield in areas subjected to different forest thinning operations in a northern New Mexico forest}

\author{
F. Atalar, O. Beyazoglu, A.G. Fernald, O.T. Burney, D.M. VanLeeuwen, and D.S. Cram
}

\begin{abstract}
Forest thinning practices play a fundamental role in natural resource management and are used to reduce forest density, particularly in the southwestern United States. Increased forest density can significantly influence fuel loads and subsequent fire severity. Moderate and high fire severity may increase surface runoff and sediment yield during postfire rainfall events. This study was conducted to evaluate the effects of thinning treatments on runoff and sediment yield in northern New Mexico forests. Four cover types were tested to evaluate how they influenced runoff and sedimentation. The four cover types included control (nonthinned), interspace (between slash piles), lop-scatter (slash was scattered and burned), and pile (slash was piled and burned). In addition, each cover type was tested on two categories of slopes: mild slopes (<5\%) and moderate slopes (5\% to $20 \%)$. Rainfall simulations $(\sim 16 \mathrm{~cm}$ $\mathrm{h}^{-1}$ ) for both dry and wet runs were used to measure runoff and sediment yield in 2015 and 2017. Results showed pile treatments had significantly higher time to runoff initiation than did control plots during dry runs. Time to peak runoff was significantly different in mild slope (38.1 $\mathrm{min})$ than moderate slope $(25.4 \mathrm{~min})$ in the dry run. Wet run time to peak runoff was found to be greater under the pile treatment as compared to other treatments. Sediment yield was significantly greater on moderate slopes in pile and lop-scatter treatments as compared to control for dry runs. For wet runs, a significant effect was detected between slopes; moderate (greater) slopes produced greater sediment than mild (lesser) slopes. The pile treatments may provide beneficial impacts for watersheds despite the delayed peak runoff in response to rainfall on milder slopes. However, high sediment yield with runoff for pile thinning treatments in steeper slope locations will be important to include when evaluating management impacts on natural resources in the future. Overall, this case study shows that thinning activities in conifer forests of New Mexico have the potential to impact the hydrological function of the watershed and should be considered as part of an overall forest and watershed management strategy.
\end{abstract}

Key words: forest thinning—rainfall simulation—runoff—sediment yield

\begin{abstract}
Forest restoration thinning treatments are useful for reducing fire severity and ecological drought stressors such as insects and disease. Thinning also is useful to address water yield challenges (Luo et al. 2018). Thinning treatments reduce stem density and thereby increase soil water availability through reduced transpiration and decreased canopy cover (Aussenac 2000). Bosch and Hewlett (1982) reviewed 94 paired-watershed studies from different parts of the world to see how forest cover affects water yield.
\end{abstract}

The review found that for every 10\% reduction in forest overstory water yield increased by $40 \mathrm{~mm}$ in coniferous forests and by $25 \mathrm{~mm}$ in deciduous forests where mean annual precipitation exceeds 450 to $500 \mathrm{~mm} \mathrm{y}^{-1}$.

Forest and land managers utilize a variety of silvicultural practices intended to increase water yield and reduce evapotranspiration across forest watersheds (Hibbert 1965). Forest thinning is one such silvicultural method that is typically used to reduce stand density to improve fire resilience, growth

Received August 16, 2018; Revised October 9, 2020; Accepted December 8, 2020. rates for commerical timber markets, or both, while simultaneoulsy enhancing stand structure and runoff at watershed scales (Lesch and Scott 1997). After the thinning process, more sunlight reaches the ground increasing both the amount and density of the understory cover (Yanai et al. 1998; Thomas et al. 1999; Dodson et al. 2008). These understory changes can conceivably affect water infiltration and flow direction near the surface (Lane and Mackay 2001; Grace et al. 2006).

In the southwestern United States, forested watersheds are important sources of water supply for domestic and agricultural needs (Robles and Enquist 2010). Many regions of the semiarid southwest are experiencing growing competition for fresh water; this is a serious issue in these areas. This demand makes it necessary to manage forested watersheds and to effectively manage water resources. Natural resource managers have determined that reducing forest density is an effective way to change water yield (Hibbert 1965; Troendle and Leaf 1980; Bosch and Hewlett 1982).

One obstacle to increasing water resources for municipal and industrial purposes in the southwestern United States is that the number of densely forested areas has expanded over the past 100 years (MacDonald and Stednick 2003). The major factors that have increased tree densities are fire suppression and deficiencies in forestry practices such as harvesting or thinning (Allen 1989; Swetnam and Betancourt 1990; Touchan et al. 1995; Swetnam and Baisan 2003). Increased forest density creates three major outcomes for natural resource management: reducing water yield (Triemble and Weirich 1987; MacDonald and Stednick 2003), reducing

Furkan Atalar is a forest engineer at the Research Institute for Forest Soil and Ecology, Republic of Turkey General Directorate of Forestry, Eskişehir, Turkey. Onur Beyazoglu is a forest engineer at the General Directorate of Combating Desertification and Erosion, Republic of Turkey Ministry of Agriculture and Forestry, Ankara, Turkey. Alexander G. Fernald (corresponding author) is a professor at New Mexico State University, Las Cruces, New Mexico, United States. Owen T. Burney is an associate professor at New Mexico State University, Mora, New Mexico, United States. Dawn M. VanLeeuwen is a professor at New Mexico State University, Las Cruces, New Mexico, United States. Douglas S. Cram is an associate professor at New Mexico State University, Las Cruces, New Mexico, United States. 
herbaceous vegetation (Cooper 1960; Oliver and Ryker 1990), and increasing wildfire danger (Swetnam 1990). New Mexico forests have shown alterations from intensive livestock grazing since the late 1800s (Cooper 1960) and from the last century of fire suppression (Weaver 1964; Swetnam 1990). New Mexico's forests occupy 10 million ha (31\% of state's total land area) and supply approximately $65 \%$ of all surface waters generated by headwaters withing the state. (Furniss et al. 2010; Goeking et al. 2014). Portions of these forested areas occur in higher elevations and are important sources of water because higher elevation forests receive higher amounts of precipitation to produce runoff and groundwater recharge (Brooks et al. 2013; Goeking et al. 2014). Appropriate management of these watersheds is crucial to better manage water supplies (Stednick 2000; MacDonald and Stednick 2003).

Thinning and other silvicultural practices can also be a beneficial management option to minimize the effect of fire severity by decreasing tree density and fuel loads. These practices (e.g., commercial harvest, commercial harvest and burn, noncommercial lop and pile, noncommercial lop-scatter, and shelterwood harvest) will reduce the severity of wildfires if applied in dense forest. Prescribed burning is a suitable management practice that restores watersheds and helps their ecologic functions (Cram et al. 2003). A combination of thinning and burning prescriptions can increase water yield (Hibbert 1965; Bosh and Hewlett 1982; Stednick 1996) and forage production (Cooper 1960) while decreasing wildfire dangers (Cram et al.2003). The potential result of decreasing forest density is a reduction in evapotranspiration while increasing water yield (Hicks et al. 1991; Sun et al. 2005). Numerous studies have projected increased water yield in forested areas after forest thinning (Bosch and Hewlett 1982; Triemble and Weirich 1987); a 20\% reduction of the basal area in a forested watershed can yield a statistically significant increase in runoff. However, treatment practices such as large-scale clear-cutting may increase the likelihood of increased sediment yield and flood risk while also negatively impacting wildlife habitat (Arthur et al. 1998; Stednick 2000; Chu and Shirmohammadi 2004).

Sediment is one of the more important nonpoint source pollutants associated with forestry management practices (Grace 2005). Disturbances such as harvesting (i.e., logging) and road-building may result in increased amounts of sediment accumulation in stream channels through soil disturbance (Rice et al. 1979; MacDonald and Stednick 2003). After successful treatments, ground can be covered by litter and vegetation, which diminish soil erosion and runoff while promoting increased infiltration (Baker et al. 1995). Research methods using simulated rainfall have been established as a cost-effective way to measure soil erosion (Sheridan et al. 2008). Rainfall simulation does this by controlling the amount of precipitation as well as the length of time and the intensity of the precipitation, making it a convenient tool for research in hydrological soil procedures (Martínez-Murillo et al. 2013).

Our study study provides improved knowledge about the hydrologic dynamics of forest management practices and hydrologic processes in a northern New Mexican forest. This case study was conducted to evaluate the effects of forest thinning practices on runoff and sediment yield. We hypothesized that, compared to unthinned forest, thinned and burned forest stands with piled/ interspace and lop-scatter slash would have increased surface runoff and sediment yield during simulated rainfall.

\section{Materials and Methods}

Study Area. The fieldwork was completed within the Walker Flats Grazing Allotment in the Pecos/Las Vegas Ranger District of the Santa Fe National Forest near Mora, New Mexico (latitude 3600'58.15" N, longitude $105^{\circ} 27^{\prime} 37.78^{\prime \prime} \mathrm{W}$; figure 1). The highest elevation in the forest where the plots were located is approximately $2,926 \mathrm{~m}$ while the lowest point is $2,680 \mathrm{~m}$. The study was conducted during the months of June, July, and August in two different years, 2015 and 2017. Total annual precipitation was $92 \mathrm{~cm}$ for 2015 and $63 \mathrm{~cm}$ for 2017. The mean minimum and maximum temperatures were $-0.1^{\circ} \mathrm{C}$ and $15.3^{\circ} \mathrm{C}$ for 2015 , and they were $0.7^{\circ} \mathrm{C}$ and $16.3^{\circ} \mathrm{C}$ for 2017 (NOAA/ NCDC 2020).

The study area included two different types of forest structure defined by the different percentages of tree species. The first type is classified as ponderosa pine and was composed of more than $60 \%$ ponderosa pine (Pinus ponderosa C. Lawson). The second type is classified as a mixed conifer, which has less than $60 \%$ ponderosa pine. The other tree species in these stands included white fir (Abies concolor [Gord. \& Glend.] Lindl. ex Hildebr), Douglas fir (Pseudotsuga menziesii [Mirb.] Franco var. glauca [Beissn.]), limber pine (Pinus flexilis), and aspen (Populus tremuloides Michx).

Thinning Treatment. The Walker Flats Collaborative Forest Restoration Program (CFRP) project consisted of 13 different forest stands that received multiple thinning and burning treatments spanning from 2005 to fall 2008. The treatments were applied according to the prescription written by the US Forest Service for the Walker Flats Grazing Allotment, which was divided into three units: Walker, Corrales, and Encinal. According to the CFRP project, each type of stand had its own prescription. A more general prescription for all three follows, which was issued as guidance to contract thinners: Trees "over 11.9 inches" $(30.2 \mathrm{~cm})$ diameter at breast height were not cut; the stand was thinned to leave 80 to 100 trees $\mathrm{ac}^{-1}$ (200 to 247 trees $\mathrm{ha}^{-1}$ ); and appropriate spacing between residual trees was kept $6 \mathrm{~m}$, except where clumping or openings were left. The tree species preference selection was as follows: ponderosa pine, limber pine, aspen, and Douglas fir; $15 \%$ to $20 \%$ of residual trees should be left in clumps (clumps were defined by 2 to 6 trees with overlapping crowns or quite close to each other); and there should be 3 to 7 tree groups ac ${ }^{-1}$ ( 7 to 17 tree groups $\left.\mathrm{ha}^{-1}\right)$. Slash was piled and was located in conical shape away from crowns of trees. Pile-including fine fuels (less than $10 \mathrm{~cm}$ diameter) and boles (greater than 10 $\mathrm{cm}$ diameter)—should be left $1.8 \mathrm{~m}$ away from remaining trees (New Mexico State University 2009).

Thinning prescriptions resulted in the following treatments: control, interspace, lop-scatter, and pile. Control treatments were nonthinned areas selected in close proximity to thinned units in an attempt to mirror preharvest conditions. Control areas had dense closed canopy conditions with little to no understory. Lop-scatter treatments were selected within thinned areas where slash material was treated on the ground with a lop-scatter approach. Pile treatments were created in thinned areas in which slash material was piled and then burned. These pile treatments included fine fuels and boles. Fine fuels were less than $10 \mathrm{~cm}$ diameter in size, and boles were greater than $10 \mathrm{~cm}$ diameter in size. Burn pile size was based on US Forest Service guidelines that recommend 


\section{Figure 1}

Specific location of research plots in Walker Flats Grazing Allotment in Santa Fe National Forest, New Mexico. The following describe the treatments in the figure: $C=$ control, $P=$ pile and burn, $\mathrm{L}=$ lop-scatter, and I = interspace.

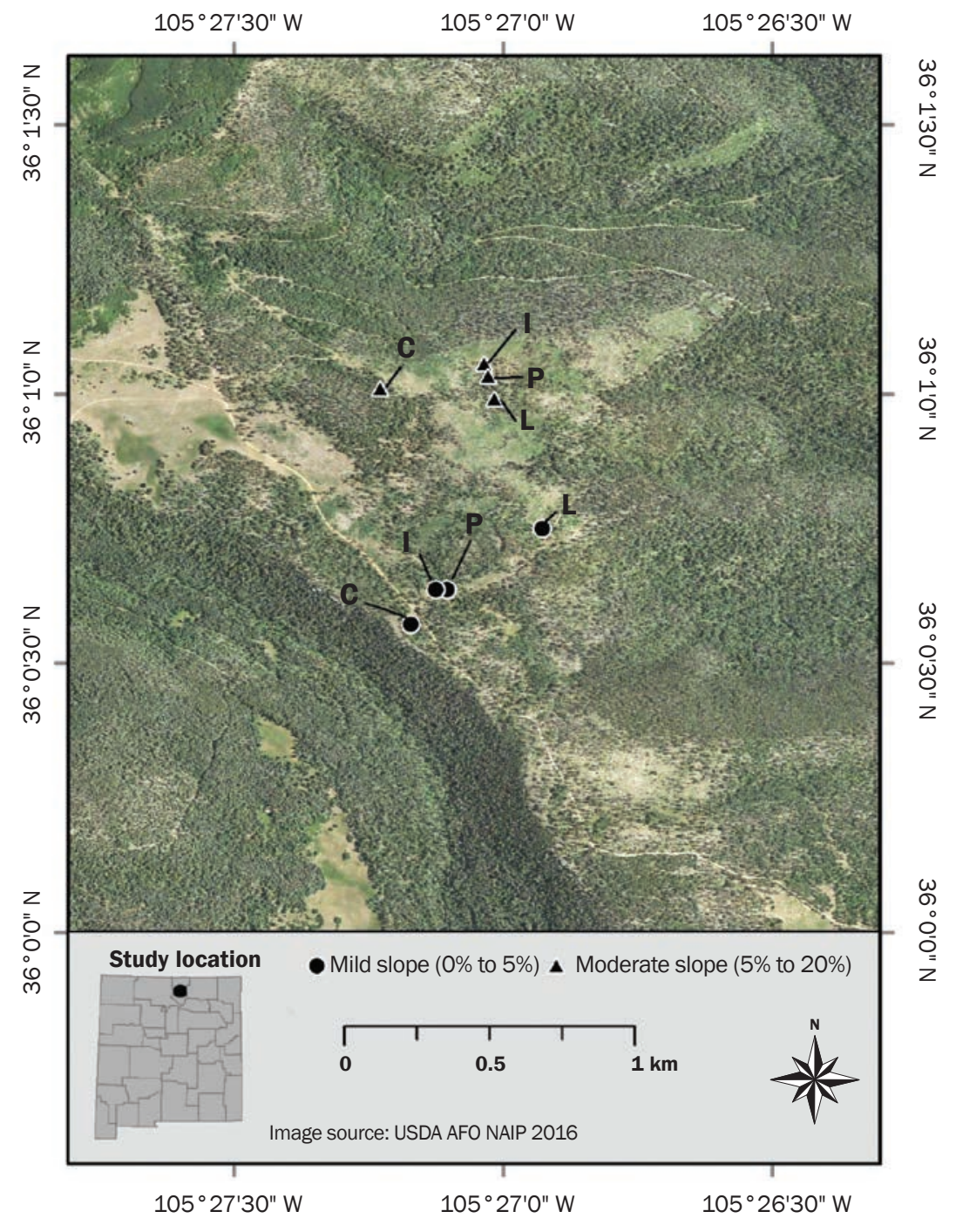

piles be built to $1.83 \times 1.83 \times 1.83 \mathrm{~m}$ or $6.12 \mathrm{~m}^{3}$ of slash. The burn pile footprint was approximately $3.34 \mathrm{~m}^{2}$. To select interspace plots, a pile was first randomly chosen (independently of the piles selected for the pile treatment). Then, starting at this point, a random azimuth was selected, along which the closest pile was then selected as the second chosen pile. The interspace plot was defined as the midpoint between these two piles. While interspace and pile were components of the same treatment protocol, it is expected that interspace areas and areas under the burn piles would respond differently to the treatment protocol. These interspace and piles were not paired together for the analysis given that they were randomly selected points. Across the pile treatment area, the actual burn piles represented less than $5 \%$ of the total area compared to the interspace. Additionally, we intended to explore whether the more intense burning associated with piles resulted in differences from the less intense burning related to lop-scatter treatment.

The Walker unit was thinned in strips for part of a monitoring study in 2005, and it was also thinned over the entire area from May of 2007 through December of 2008. The Corrales unit was thinned approximately 25 years earlier, and the Encinal unit was thinned between September of 2005 and July of 2006. Also, in this study area, pre- scribed burning was conducted in the fall of 2008, except on the Encinal unit.

Methods. The study design was based on an experimental design established in conjunction with the Walker Flats CFRP (New Mexico State University 2009). In this study design, two locations (described below as blocks for the statistical analysis) were established and defined by their slope: location 1 was an area with a mild slope ( $<5 \%$ slope) and location 2 was an area with moderate slope (>5\% to $20 \%$ slope) (figure 2). No locations were established in the steep slope areas, because treatment was not allowed under forest management guidelines due to the erosion risk. Four different treatments were established in each location in the Walker Flats study area. Each location had a control, interspace, lop-scatter, and pile in different portions of the site. Control treatments were established in areas where no thinning or burning activity had been practiced. Lop-scatter, pile, and interspace treatments had thinning and burning activities in the Walker Flats Grazing Allotment. Silvicultural thinning had been practiced before slash was scattered and burned on the ground in lop-scatter treatments. Similarly, in pile treatments, thinning had been applied before the slash was piled and burned. The interspace treatments were established between separately selected slash piles.

Rainfall simulations (Wilcox et al. 1986) were used in each plot to measure precipitation, runoff, and sediment yield (SY). The portable rainfall simulator was described by Madrid et al. (2006), and was used in previous studies (Cram et al. 2007; Fernald et al. 2012). The simulator included a tripod, a one-quarter G10 full jet irrigation nozzle (Spraying Systems Co., Wheaton, Illinois), which was vertically downward facing, a garden hose, a 757 L water tank, and a Pacer water pump (Pacer, Lancaster, Pennsylvania) powered by a 5.5 horsepower Briggs \& Stratton engine (Briggs \& Stratton, Wauwatosa, Wisconsin). The full jet irrigation nozzle was positioned $175 \mathrm{~cm}$ above the soil surface by adjusting the legs of the tripod. Runoff rings with a $1 \mathrm{~m}^{2}$ internal area were placed directly into the soil across all four treatment plots (i.e, control, lop-scatter, pile, and interspace). In the pile treatment, rings were positioned directly over the residue from the burned piles occupying approximately one-third of the burn pile footprint. Little to no soil disturbance occurred during the installation of 


\section{Figure 2}

Description of treatments with (a) associated ring locations and (b) the sampling design for the treatments across the two slope locations.

(a)

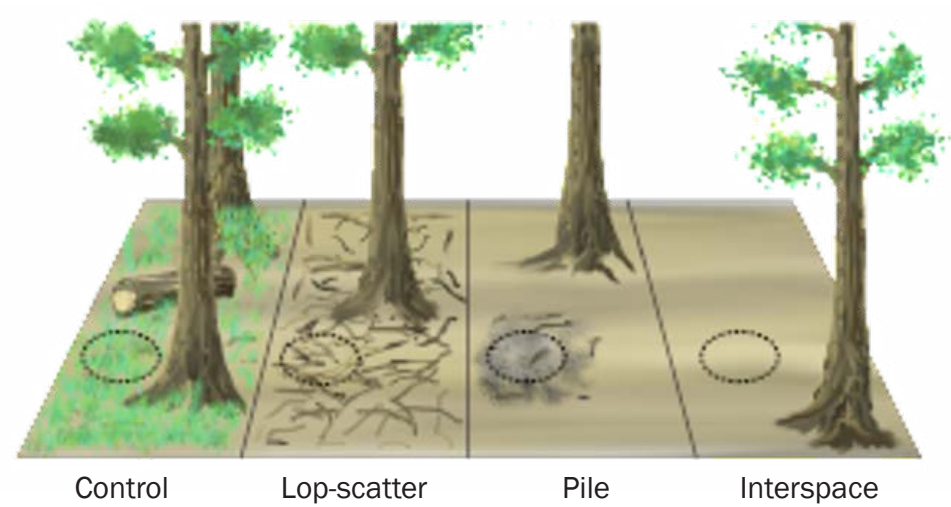

(b)

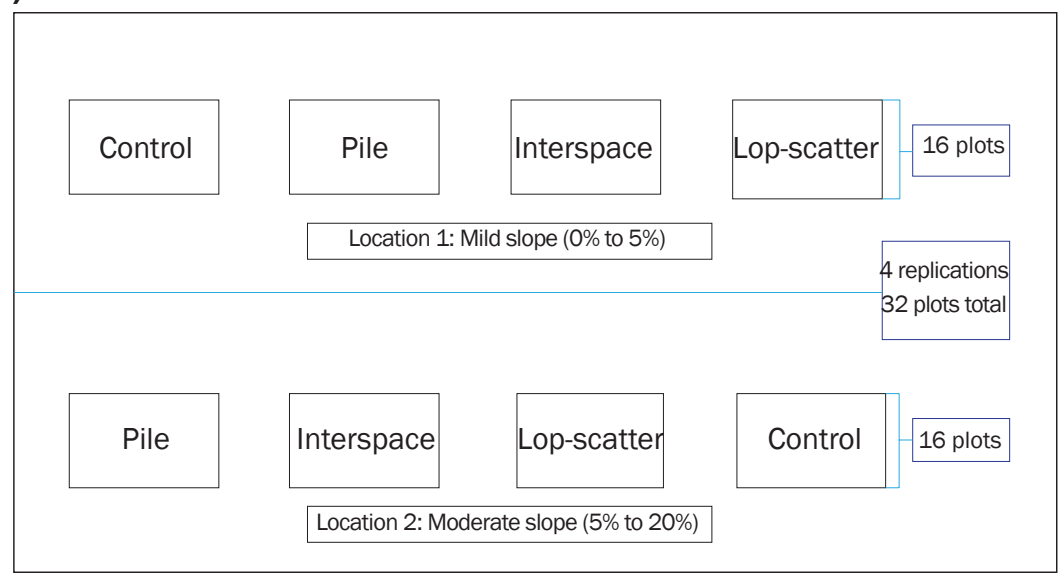

runoff rings. The nozzle was placed over the center of the ring. The water pressure used for the rainfall simulation was maintained at $68.9 \mathrm{kPa}$ target water pressure by using a pressure regulator (Senninger Irrigation Inc., Clermont, Florida) with $10.3 \mathrm{kPa}$ fluctuation around the target pressure.

A total of 32 plots ( 16 plots in the mild slope block and 16 in the moderate slope block) were established for the measurements. During 2015 and 2017, the same locations were used based on the 2009 study design. Rainfall simulations of $1 \mathrm{~h}$ were run for each plot (a total of 64). Two $60 \mathrm{~min}$ rainfall simulations were conducted. The first hour simulation was called the "dry run" and characterized antecedent soil moisture. The second simulation, run $24 \mathrm{~h}$ after the dry run, was called the "wet run" and characterized soils at field capacity. Between the two simulations, runoff rings were covered with black plastic to minimize evaporation and to maintain conditions close to soil field capacity for the wet run.
The rainfall simulator provided precipitation for $60 \mathrm{~min}$, and the average rainfall application for both dry and wet runs was approximately $16 \mathrm{~cm} \mathrm{~h}^{-1}$. For each time period, rainfall simulations were conducted 32 times for a total of 64 simulations. Precipitation $(\mathrm{cm})$, runoff $(\mathrm{mL})$, and soil moisture (\%) were measured in 5 min intervals by repeating the process 12 times for a total of $60 \mathrm{~min}$. Precipitation rates $\left(\mathrm{cm} \mathrm{h}^{-1}\right)$ were determined by taking the average of two rain gauges installed near the center of the rings. Runoff was measured in milliliters by using a $1 \mathrm{~L}$ graduated cylinder in $5 \mathrm{~min}$ intervals, and the total runoff was determined after 12 readings of 5 min runs. Small screens covered the runoff trays to prevent precipitation overspray from entering the runoff bucket. Runoff ratio $\left(\mathrm{cm} \mathrm{h}^{-1}\right)$ was calculated because we did not have equal precipitation rates among simulations. At the end of the $1 \mathrm{~h}$ period, all the runoff was collected in a large garbage container from which $1 \mathrm{~L}$ sediment samples were taken. Before tak- ing sediment samples, all runoff was robustly agitated in a garbage container providing for suspended sediment. Time to runoff initiation (TRI) was defined as the time when the collection bucket obtained the first drop of flow after the starting time of the simulator. Any lateral overflow from the rainfall simulator that fell outside the ring was not diverted into the collection bucket and was not included in the measurements. Time to peak runoff (TPK) was determined as the time when runoff volume reached its highest peak after starting time. For example, assuming the peak volume was measured during the fourth 5 min interval, then the TPK was 20 min.

The following sediment sample procedure was described by Garduno et al. (2015). Sediment samples were allowed to settle to filter the excess water from the $1 \mathrm{~L}$ bottle. Filtered samples (the $1 \mathrm{~L}$ bottle and the wet sediment) were weighed before being dried in an oven for $48 \mathrm{~h}$ at $60^{\circ} \mathrm{C}$, after which the dry sediment was weighed (in $\mathrm{g} \mathrm{m}^{-2}$ ). Then SY was calculated as kilogram per hectare.

Site characteristics were measured to describe potential influences on runoff and SY. Slope (\%) within a plot was determined using a hand level and a meter ruler. Plot litter depth $(\mathrm{cm})$ was measured at five equally spaced locations (center, north, east, west, and south) within each plot ring. Soil moisture data were collected using a Field Scout ${ }^{\circledR}$ Time Domain Reflectometer (Spectrum Technologies, Aurora, Illinois, United States) 100 Soil Moisture Sensor (table 1).A Spherical Densitometer Canopy cover was used to measure canopy cover by taking the average of measurements recorded when facing north, east, south, and west within the plots (Lemmon 1956). A $0.5 \mathrm{~m} \times 1.0 \mathrm{~m}$ rectangular quadrat was used to determine percentage understory cover (Bonham 2013). Cover classes were recorded as follows: vegetation, litter, rock, and bare soil (table 1). Rectangular quadrats were replicated five times from the plot center, facing north and south.

Data were analyzed using SAS PROC MIXED and PROC GLIMMIX software version 9.4 (SAS Institute Inc. 2013). The predictor variables were two different time periods (2015 and 2017), location defined with two slope ranges (mild and moderate), and treatment with four types (control, interspace, lop-scatter, and pile) and all interactions. Repeated measures were accounted for with a random effect defined by repli- 


\section{Table 1}

Site characteristics with mean \pm standard deviation of four forest treatments during 2015 and 2017 study periods in a mixed conifer forest near Mora, New Mexico.

\begin{tabular}{|c|c|c|c|c|c|c|c|c|c|}
\hline \multirow[b]{3}{*}{ Variables } & \multirow{3}{*}{$\begin{array}{l}\text { Location } \\
\text { (slope) }\end{array}$} & \multicolumn{8}{|l|}{ Treatments } \\
\hline & & \multicolumn{2}{|l|}{ Control } & \multicolumn{2}{|l|}{ Interspace } & \multicolumn{2}{|l|}{ Lop-scatter } & \multicolumn{2}{|l|}{ Pile } \\
\hline & & 2015 & 2017 & 2015 & 2017 & 2015 & 2017 & 2015 & 2017 \\
\hline Litter depth (cm) & Moderate & $2.5 \pm 1.5$ & $1.4 \pm 0.6$ & $1.7 \pm 0.6$ & $1.1 \pm 0.6$ & $2.0 \pm 1.0$ & $1.6 \pm 1.0$ & $1.4 \pm 0.6$ & $0.7 \pm 0.4$ \\
\hline Canopy cover (\%) & Mild & $60.9 \pm 10.7$ & $71.4 \pm 13.0$ & $22.8 \pm 14.3$ & $27.6 \pm 8.3$ & $11.1 \pm 9.7$ & $12.3 \pm 11.0$ & $30.5 \pm 5.3$ & $42.9 \pm 21.3$ \\
\hline $\begin{array}{c}\text { Total vegetative } \\
\text { cover (\%) }\end{array}$ & Moderate & $34.2 \pm 17.4$ & $53.6 \pm 17.9$ & $19.9 \pm 1.0$ & $37.2 \pm 7.6$ & $8.6 \pm 2.5$ & $25.8 \pm 8.9$ & $36.7 \pm 8.4$ & $43.3 \pm 20.5$ \\
\hline \multirow[t]{2}{*}{ Litter cover (\%) } & Mild & $75.2 \pm 5.3$ & $50.2 \pm 3.6$ & $41.2 \pm 18.4$ & $22.9 \pm 22.0$ & $20.3 \pm 13.6$ & $8.2 \pm 2.8$ & $50.2 \pm 38.7$ & $42.2 \pm 35.3$ \\
\hline & Moderate & $59.4 \pm 11.7$ & $33.7 \pm 14.2$ & $50.2 \pm 2.3$ & $38.9 \pm 17.9$ & $68.5 \pm 14.0$ & $53.2 \pm 12.2$ & $30.9 \pm 13.7$ & $23.9 \pm 16.5$ \\
\hline \multirow[t]{2}{*}{ Rock cover (\%) } & Mild & $10.2 \pm 6.7$ & $8.6 \pm 3.2$ & $3.3 \pm 4.1$ & $2.1 \pm 2.5$ & $5.2 \pm 5.4$ & $2.8 \pm 2.9$ & $0.80 \pm 1.0$ & $0.3 \pm 0.3$ \\
\hline & Moderate & 0.0 & 0.0 & $4.30 \pm 5.4$ & $4.0 \pm 3.9$ & $6.5 \pm 6.9$ & $4.2 \pm 4.5$ & $12.5 \pm 10.1$ & $10.3 \pm 6.5$ \\
\hline (\%)-dry & Moderate & $32.8 \pm 12.4$ & $25.4 \pm 2.4$ & $40.0 \pm 11.9$ & $34.4 \pm 1.2$ & $33.0 \pm 14.1$ & $23.0 \pm 2.1$ & $38.9 \pm 14.8$ & $36.4 \pm 6.0$ \\
\hline Soil moisture & Mild & $46.2 \pm 10.7$ & $35.3 \pm 5.7$ & $53.1 \pm 18.3$ & $51.1 \pm 5.2$ & $24.3 \pm 3.5$ & $41.2 \pm 4.3$ & $47.3 \pm 9.8$ & $47.9 \pm 2.4$ \\
\hline (\%)-wet & Moderate & $55.1 \pm 3.1$ & $37.4 \pm 5.3$ & $40.0 \pm 10.9$ & $41.5 \pm 9.0$ & $21.4 \pm 4.8$ & $34.2 \pm 1.2$ & $40.6 \pm 12.1$ & $46.2 \pm 5.5$ \\
\hline Initial soil moisture & Mild & $20.8 \pm 6.0$ & $11.7 \pm 4.9$ & $24.9 \pm 14.2$ & $26.2 \pm 5.7$ & $5.4 \pm 1.6$ & $18.4 \pm 7.5$ & $24.9 \pm 14.9$ & $25.4 \pm 5.0$ \\
\hline$(\%)-d r y$ & Moderate & $34.9 \pm 6.8$ & $12.0 \pm 3.0$ & $25.2 \pm 8.0$ & $13.0 \pm 1.9$ & $9.2 \pm 2.5$ & $10.2 \pm 1.7$ & $23.2 \pm 11.5$ & $13.9 \pm 3.0$ \\
\hline Initial soil moisture & Mild & $29.0 \pm 9.4$ & $22.7 \pm 7.0$ & $44.4 \pm 16.6$ & $39.5 \pm 4.7$ & $15.2 \pm 1.8$ & $27.8 \pm 8.2$ & $36.9 \pm 9.5$ & $36.2 \pm 2.6$ \\
\hline (\%)-wet & Moderate & $44.5 \pm 6.4$ & $23.0 \pm 5.0$ & $30.3 \pm 12.0$ & $31.3 \pm 2.7$ & $14.5 \pm 3.7$ & $22.2 \pm 2.3$ & $33.4 \pm 12.9$ & $33.6 \pm 7.5$ \\
\hline SY-dry & Mild & $8.2 \pm 1.5$ & $4.0 \pm 1.4$ & $6.8 \pm 1.7$ & $3.8 \pm 1.2$ & $6.7 \pm 3.5$ & $5.8 \pm 0.8$ & $7.3 \pm 4.8$ & $4.9 \pm 1.2$ \\
\hline SY-dry & Moderate & $9.5 \pm 2.8$ & $1.5 \pm 0.8$ & $11.7 \pm 3.7$ & $11.8 \pm 13.7$ & $11.8 \pm 3.6$ & $10.1 \pm 7.9$ & $12.6 \pm 1.0$ & $12.1 \pm 4.4$ \\
\hline SY-wet & Mild & $4.8 \pm 2.7$ & $4.9 \pm 2.3$ & $6.7 \pm 1.7$ & $7.1 \pm 1.1$ & $8.1 \pm 3.3$ & $9.5 \pm 4.4$ & $8.9 \pm 3.1$ & $5.4 \pm 0.6$ \\
\hline SY-wet & Moderate & $8.0 \pm 3.5$ & $7.1 \pm 1.1$ & $9.5 \pm 3.6$ & $15.8 \pm 12.6$ & $7.4 \pm 3.3$ & $9.3 \pm 1.1$ & $9.1 \pm 6.3$ & $9.9 \pm 2.0$ \\
\hline
\end{tabular}

Notes: $n=4$ plots in each of the four treatments, and measurements were taken in the year cited after all treatments were applied. SY $=$ sediment yield.

cation within location by treatment. The response variables were $\log$ transformed runoff ratio, TRI (sec), TPK (min), and SY $\left(\mathrm{kg} \mathrm{ha}^{-1}\right)$. A generalized linear model (PROC GLIMMIX) using the gamma response distribution with the log link was applied to TRI (Stroup 2012); inverse linked estimates are reported. All other variables used analyses that assumed a normal response distribution (PROC MIXED), but runoff ratio was $\log$ transformed to stabilize the variance (Kuehl 1994); back transformed estimates were reported. The outlier strategy identifying outliers as having studentized residuals with magnitudes greater than 3.0 was used (Ramsey and Schafer 2002). Significant effects were explained using pairwise comparisons among least square means. For back transformed estimates, a 95\% confidence interval was reported, or standard errors were obtained using the delta method. Statistical significance value was established as 0.05 alpha level for all variables.

\section{Results and Discussion}

Runoff Ratio. There were no significant effects $(p>0.05)$ in $\log$ transformed runoff ratios for the dry run. Dry run runoff ratios ranged from 0.006 to 0.621 . The median was 0.101 . Wet runs also showed no significant treatment effects $(p>0.05)$ for $\log$ transformed runoff ratio when using all data points. Wet run runoff ratios ranged from 0.001 to 0.660 with a median of 0.113 In re-analysis, with a single outlier in the interspace treatment for mild slope in 2015 removed (with runoff ratio 0.001), however, there were significant location, treatment, and location by treatment by year effects in the log transformed runoff ratio.

With back transformed log runoff ratio analysis after one data point removed, for moderate slope in 2015 , the control treat- ment was significantly lower than other treatments. In 2017 mild slope, the control was lower than lop-scatter. Also, there were significant differences when comparing locations by year means within control treatments, which was observed in the 2015 study period for moderate slope. Although the log transformed runoff ratios of the pile treatments were numerically higher than those of the control estimates in every year and location combination, the difference was significant only for moderate slope in 2015 in the analysis with the outlier removed, 0.193 $( \pm 0.095)$ (figure 3$)$.

Differences in runoff ratios were expected; however, no differences were noticed in dry runs in contrast with the wet run results. Our hypothesis, that a thinning treatment that was followed by a burning prescription would increase runoff, was confirmed for wet run results but differed by year and treatment for the highest valued ratios. These differ- 


\section{Figure 3}

Back transformed log runoff ratio during wet runs from treatments by location by year interaction effect with one outlier data point removed in a New Mexico forest near Mora, New Mexico. Lowercase letters represent the comparison among treatments within each location by year combinations. Means followed by same letters were not significantly different at 0.05 level. SEs obtained using delta method.

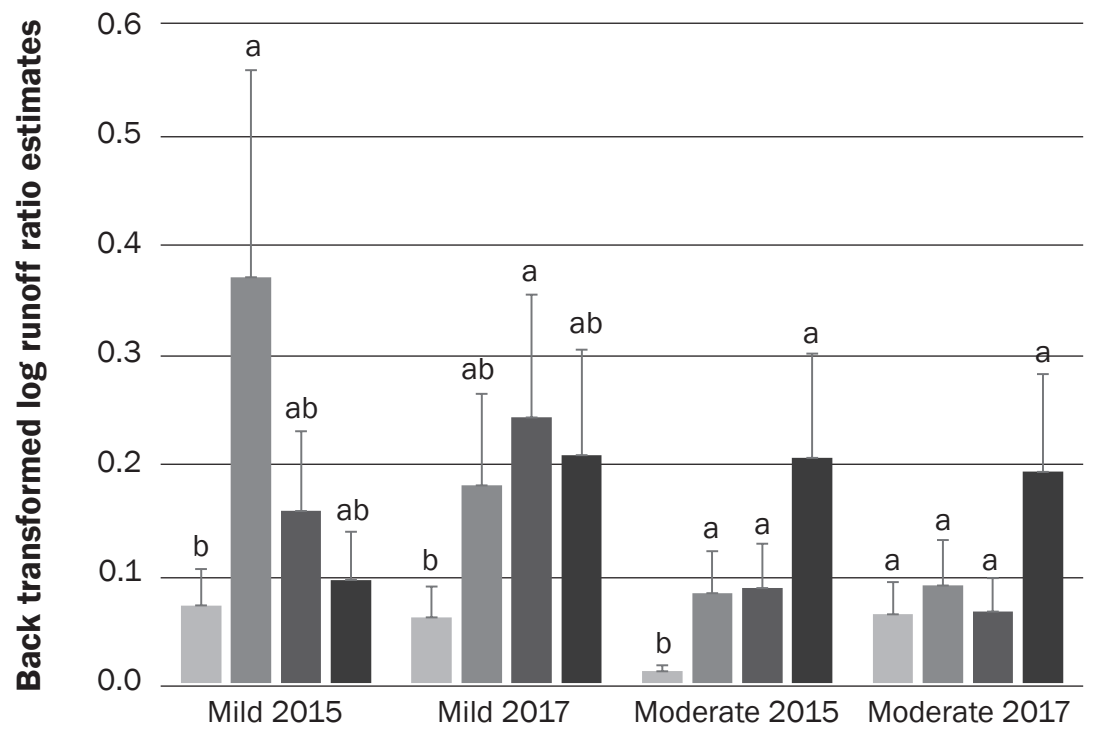

\section{Legend}

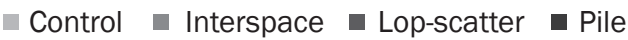

( \pm 32.45$), 434.81$ ( \pm 76.48$), 359.02$ ( \pm 63.16$)$, and $413.64( \pm 72.77)$. For both years the estimate for the pile treatment was more than double the estimate for the control.

For the TRI during the wet runs, there was evidence for treatment effect, year effect, and the interaction of treatment by year effect. TRI means in 2017 were numerically higher than in 2015 for all treatments; significant differences were, however, detected between pile versus control and lop-scatter and interspace versus control and lop-scatter in 2015 (table 2). In 2015, the ratio of the interspace mean to the control mean was estimated to be 1.58 ( \pm 0.31$)$; however, the ratio of the pile mean to the control mean was estimated to be 2.32 ( \pm 0.46$)$ (table 2 ).

Fernald et al. (2012) suggested that litter depths (control sites) and/or slash (thinned sites) possibly influenced the delayed TRI due to having absorbed water. Litter or other residuals have resulted in delaying flow length through to soil surface by creating water flow path (Yanosek et al. 2006). The pile acted like other residuals because during dry runs TRI from the pile treatment was greater the control mean (table 1). It might be expected as litter depth increases, TRI is delayed. Runoff response may also be determined by vegetation cover condition because high vegetation cover rate provides decreased runoff yield and raindrop effect to bare soil (Robichaud et al. 2000; Cerdà and Doerr 2005). In our result for TRI in wet runs, vegetation cover may explain the year differences for control, interspace, and lop-scatter; the ratio for vegetation cover from 2015 to 2017 increased as $2.04,1.26$, and 1.51 times, respectively. Another reason for higher TRI in pile treatment may be due to the woody materials and microsite characteristics in rings. In addition, the areas under study were heterogeneous, which was reflected in highly variable site characteristics and high response variability. To increase the power to detect large and moderate differences, future studies would require larger samples sizes.

The yield of woody materials could act as a small debris dam in the ring, and this may have affected the time length of the first drop of water seen in buckets. Woody materials (i.e., branches, logs, and stumps) play an important role for the forest ecosystems, including surface runoff and sediment transportation relationships. As the rainfall droplets impact the ground surface, existence of woody material will buffer the impact 
and slow the surface runoff of the mineral soil. When the runoff velocity is reduced or slowed, it will affect the TRI. Also, this would result in slowing of sediment transportation (Vinge and Pyper 2012).

Time to Peak Runoff. During dry runs TPK was significantly higher for the mild slope location (38.14 [ \pm 3.30$] \mathrm{min})$ than the moderate slope location $(25.44[ \pm 3.30] \mathrm{min})$. TPK had a significant treatment by location by year interaction effect in wet runs. During the 2017 study period there was no statistically detectable effect among the treatments at either location. However, in 2015 at mild slope, the control treatment had significantly lower response than the lop-scatter and pile treatments (figure 5). For moderate slope in 2015, interspace had significantly higher response than lop-scatter and control. Although the pile treatment only produced significant effects in mild slope locations in 2015 , it had a numerically higher estimated TPK than did the control treatment within each year-location combination. Averaging across years and locations, the pile treatment mean was estimated to be 20.55 ( \pm 6.46$) \mathrm{min}$ higher than the control means: $43.81( \pm 4.57)$ min versus $23.27( \pm 4.57) \mathrm{min}$, respectively.

No treatment effect was observed for TPK during dry runs, corresponding to similar results by Garduño et al. (2015) that found that averaged TPK was 33.74 min for control and $38.59 \mathrm{~min}$ for thinned plots. The mild slope of a location was less steep than the moderate slope, and this may have influenced peak runoff during dry runs because water flow moved slowly. Our results for wet runs partially confirmed the results of Madrid et al. (2006), who found that treated areas provided more delayed effect for runoff than the untreated control.

Litter might have affected TPK by absorbing water because of providing delayed peak runoff according to Garduño et al. (2015). Although our results were not confirmed using the litter depth factor, microsite characteristics such as slope and density of residual woody material in the pile treatment may have explained why TPK in pile treatments was longer compared to the control within each year by location combination. Another factor that explains the differences between treatments for TPK in wet runs may be a function of soil texture and rooting depth, which influence soil water storage capacity (Lal and Shukla 2004). As soil water storage capacity is high, depending on silt and

\section{Figure 4}

Time to runoff initiation with inverse linked estimates during dry run rainfall simulations in 2015 and 2017 from treatments in a New Mexico forest near Mora, New Mexico. Lowercase letters do not differ significantly at the 0.05 alpha level.

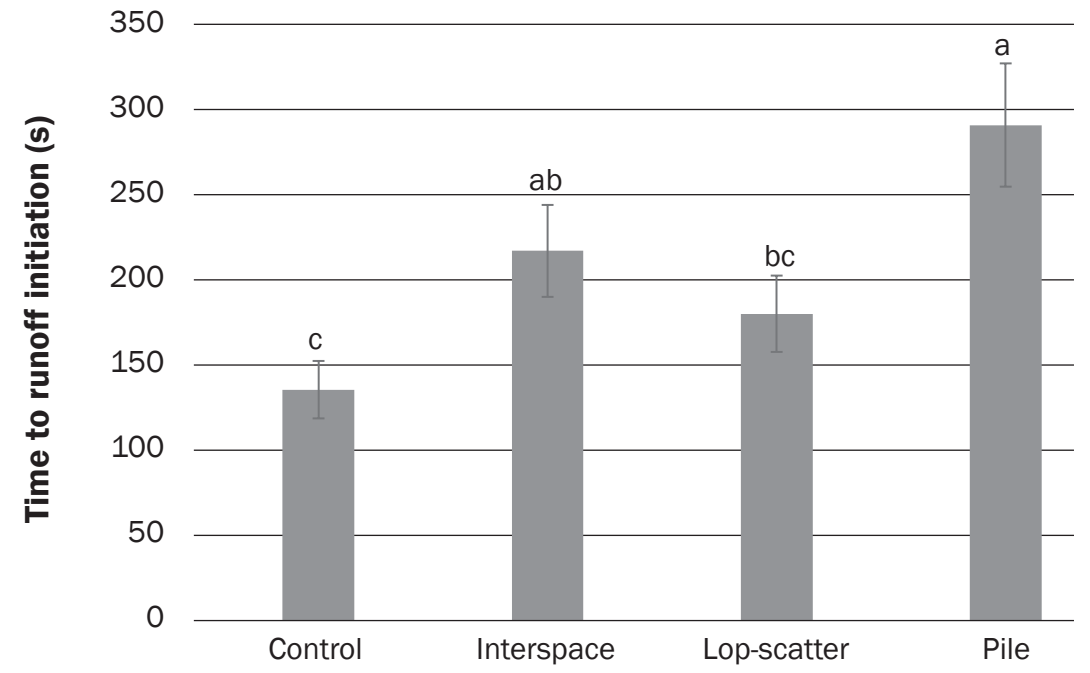

\section{Table 2}

Inverse linked estimates $( \pm$ SE) for time to runoff initiation response to treatment by year effect for the wet run.

\begin{tabular}{|c|c|c|c|c|c|}
\hline \multicolumn{2}{|c|}{$\begin{array}{l}\text { Treatment } \\
\times \text { year }\end{array}$} & \multirow{2}{*}{$\begin{array}{l}\text { Control } \\
80.31 \pm 11.17 \mathrm{~b}\end{array}$} & \multirow{2}{*}{$\begin{array}{l}\text { Interspace } \\
126.67 \pm 17.61 \mathrm{a}\end{array}$} & \multirow{2}{*}{$\begin{array}{l}\text { Lop-scatter } \\
83.36 \pm 11.59 \mathrm{~b}\end{array}$} & \multirow{2}{*}{$\begin{array}{l}\text { Pile } \\
186.09 \pm 25.87 a\end{array}$} \\
\hline Year & 2015 & & & & \\
\hline & 2017 & $207.33 \pm 28.83 a$ & $248.44 \pm 34.55 a$ & $196.32 \pm 27.29 a$ & $215.80 \pm 30.07 a$ \\
\hline \multicolumn{2}{|c|}{$P$-value } & $<0.0001$ & 0.0022 & 0.0002 & 0.4586 \\
\hline
\end{tabular}

Notes: Lowercase letters represent the comparisons in a row among the treatments within time. Means followed by same letters were not significantly different at 0.05 level. $P$-values correspond to year comparison in each treatment.

clay particles content, runoff can be delayed (Schüler 2006). Silt and clay particles have more surface area, which tends to hold more water than sandy soil. Pile and lop-scatter treatments did partially delay TPK in the wet run in 2015 for mild slope location. Soil had sandy loam features in control and lop-scatter treatments, and clay loam features in pile and interspace treatments. This may have referred to the difference between control and pile treatments; control peak was reached in $20.55 \mathrm{~min}$ less than pile treatment by averaging across year and location combination. Additionally, when pile and interspace plots were combined because these plots were randomly distributed in the same area, a significant treatment effect was detected for TPK. In this case, the combined treatment plots were significantly greater than the control for wet runs.
Sediment Yield. No treatment produced significant effects in the analysis using all data during dry runs. However, in a re-analysis with a single outlier removed from the interspace treatment in the moderate slope, the interaction of treatment by location effect was significant. The moderate slope had a higher SY than the mild slope in lop-scatter and pile treatments. On the moderate slope, the pile and lop-scatter treatment had significantly higher SY than did the control (table 3). The findings for interspace treatments were sensitive to the single outlier; in the analysis using all data, the mean for the interspace treatment, $11.74( \pm 1.81) \mathrm{kg} \mathrm{ha}^{-1}$, was similar to the mean for the pile treatment, $12.39( \pm 1.81) \mathrm{kg} \mathrm{ha}^{-1}$ (table 3). However, removing a single outlier with SY value 32.3 $\mathrm{kg} \mathrm{ha}^{-1}$ reduced the mean to $8.32( \pm 1.24)$ $\mathrm{kg} \mathrm{ha} \mathrm{h}^{-1}$. A significant year main effect was 


\section{Figure 5}

Time to peak runoff means during wet runs from treatments by location by year interaction effect in a New Mexico forest near Mora, New Mexico. Lowercase letters represent the comparison among treatments within each location by year combinations. Means followed by same letters were not significantly different at 0.05 level.

\section{0}

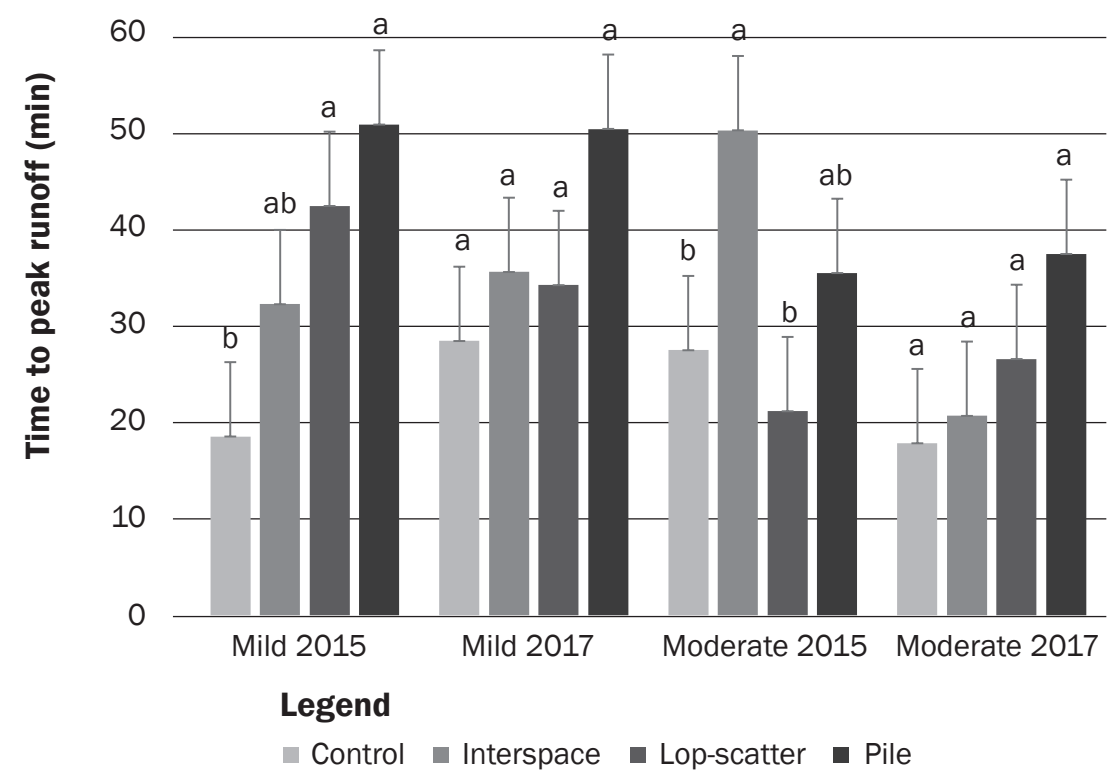

detected with $3.44( \pm 0.82) \mathrm{kg} \mathrm{ha}^{-1}$ higher SY in 2015 than in 2017.

For SY during the wet runs, there were no significant effects in the analysis using all data. In a re-analysis with a single outlying data point removed, the location effect for SY was significant. With one data point removed, the moderate slope location had higher SY (8.71 $\left.\pm 0.56 \mathrm{~kg} \mathrm{ha}^{-1}\right)$ than the mild slope location $\left(6.95 \pm 0.55 \mathrm{~kg} \mathrm{ha}^{-1}\right)$. However, when all data were included, the moderate slope location estimated SY was $9.47( \pm 0.87) \mathrm{kg} \mathrm{ha}^{-1}$ versus the mild slope location SY of $6.95( \pm 0.87)$ $\mathrm{kg} \mathrm{ha}{ }^{-1}$. In the data set for SY, an outlier was identified (high value of $34.5 \mathrm{~kg} \mathrm{ha}^{-1}$ ) in an interspace plot with a moderate slope in 2017 and was subsequently removed from the analysis.

Our original hypothesis that thinning treatment followed by burning would increase SY was partially supported by findings for pile and lop-scatter treatments. This hypothesis was confirmed only in treatments for dry runs on a moderate slope. However, slope was the primary indicator for both dry and wet runs. This result corresponded with the findings of Fernald et al. (2012), where the magnitude of slope is related to higher levels of SY. Higher runoff ratio with bare soil may have influenced the high amount of SY in pile treatments at moderate slope because erosion processes can be explained by the bare soil in rainfall events (Zemke 2016). The significant effects of the pile and lop-scatter treatments might be explained due to the higher bare soil cover as compared to the control (table 1). Additionally, as the soil surface is covered by less residual vegetation such as slash (Robichaud et al. 2005) and needles (Pannkuk and Robichaud 2003), SY may increase. Our results confirm that the moderate slope had lower total vegetation cover (table 1) in pile/interspace and lop-scatter treatments than did the control when compared to the mild slope. This might have explained the higher SY in those treatments. Land and forest managers should consider the pile and lop-scatter treatments on mild slopes as a beneficial option to decrease both forest density and wildfire risk because they would have little influence on sediment response in the watershed even with minor increase in runoff.

High levels of runoff may result in an increase in SY transportation to streams. As a result, sedimentation will likely lead to physical disruption of the hydraulic characteristics of the stream channel. For example, high levels of SY can reduce the depth of the stream channel and thus increase the risk for flooding to downstream users (Eslamian 2014).

Table 3

Dry run sediment yield $\left(\mathrm{kg} \mathrm{ha}^{-1}\right)$ estimates and inferences.

\begin{tabular}{|c|c|c|c|c|c|c|}
\hline & & \multicolumn{5}{|c|}{ Sediment yield $\left(\mathbf{k g ~ h a ^ { - 1 } )}\right.$} \\
\hline \multicolumn{2}{|c|}{ Treatment $\times$ location } & Control & Interspace & Lop-scatter & Pile & $P$-value \\
\hline \multirow[t]{3}{*}{ Location } & Mild & $6.07 a$ & $5.33 a$ & $6.23 a$ & $6.11 a$ & 0.9443 \\
\hline & Moderate & $5.45 c$ & $8.32 b c$ & $10.93 a b$ & $12.39 a$ & 0.0015 \\
\hline & Moderate (all)* & 5.45 & 11.74 & 10.93 & 12.39 & \\
\hline$P$-value** & & 0.7081 & 0.0908 & 0.0080 & 0.0007 & \\
\hline
\end{tabular}

Notes: Treatment by location estimates and inferences were based on analysis with one data point removed and estimates for the treatments in the moderate slope from the analysis using all data $\left(\mathrm{kg} \mathrm{ha}^{-1}\right)$. Lowercase letters represent the comparisons in a row among the treatments within location. Means followed by same letters were not significantly different at 0.05 level. Standard error is 1.81 using all data points. Standard error is 1.15 for all data points after removing one data point from interspace in moderate slope.

*Estimate based on analysis using all data, including the single interspace outlier.

**P-value compares the mild to the moderate locations based on analysis with outlier removed. 


\section{Summary and Conclusions}

The main objective of this study was to evaluate the effect of thinning treatments followed by burning on runoff and SY by using controlled simulated rainfall. Results showed that during wet runs, the log runoff ratio was greater for pile than for control treatments in each year-location combination. TRI was statistically greater on pile/interspace treatments compared to the control during dry runs. However, during wet runs, significant differences among treatments were detected only in 2015 . The results indicate that the mild slope $(<5 \%)$ location had a significantly higher TPK during the dry run than did the moderate slope (5\% to $20 \%$ ) location. The TPK was greater for pile treatments than for the control for each year-location combination during wet runs. For SY, there were significant differences between mild and moderate slopes, with greater SY on moderate slopes.

The results of this research suggest that forest managers utilizing pile treatments (combined with interspace) in their thinning and burning prescriptions on moderate slopes should consider the negative impacts on SY. However, a positive side to these treatments could be increasing runoff that would be beneficial for the entire watershed. Additionally, the combined pile and interspace treatments might be influential in terms of peak runoff and thereby can be important for watershed health by providing delayed output during high storm events. If water flow delivered to streams is prolonged, reduced surface runoff will be associated with reduced SY, providing a measure of protection for stream water quality.

Further research is recommended to provide information about the best combination of thinning and burning practices that can help decrease wildfire risk and forest density while promoting an increase in water yield for downstream users. It is critical to minimize site and plot variation (e.g., soil type, slope, aspect, etc.) outside of the treatment structure for proper replication, randomization, and noise reduction. Additionally, greater information on microsite characteristics (e.g., litter, woody debris, and vegetation cover) should be collected to help better explain the influence of treatments on the response variables (i.e., runoff ratio, TRI, TPK, and SY). Future studies should evaluate treatment response over a longer period of time $(10+$ years) and across multiple sites to have a broader understanding of the effects of thinning, burning, and slash treatments on runoff, SY, and overall forest hydrology.

\section{Acknowledgements}

We thank all the staff of the John T. Harrington Forestry Research Center and the New Mexico Water Resources Research Institute (WRRI) for their invaluable cooperation. Also, we want to thank the Ministry of National Education, Turkey, and the General Directorate of Forestry, Turkey, for their support of this research. This study was funded by the WRRI and Range Improvement Task Force (RITF) of New Mexico State University, and also supported in part by the New Mexico Agricultural Experiment Station.

\section{References}

Allen, C.D. 1989. Changes in the landscape of the Jemez Mountains, New Mexico. PhD dissertation, University of California Berkeley.

Arthur, M.A., G.B. Coltharp, and D.L. Brown. 1998. Effects of best management practices on forest streamwater quality in eastern Kentucky. JAWRA Journal of the American Water Resources Association 34(3):481-495.

Aussenac, G. 2000. Interactions between forest stands and microclimate: Ecophysiological aspects and consequences for silviculture. Annals of Forest Science 57(3):287-301.

Baker, M.B., L.F. DeBano, and P.F. Ffolliott. 1995. Soil loss in piñon-juniper ecosystems and its influence on site productivity and desired future condition. In Desired Future Conditions for the Pinon-Juniper Ecosystem, 9-15. Fort Collins, CO: USDA, Forest Service, Rocky Mountain Research Station.

Bonham, C.D. 2013. Measurements for terrestrial vegetation. Hoboken, NJ: John Wiley \& Sons.

Bosch, J.M., and J.D. Hewlett. 1982. A review of catchment experiments to determine the effect of vegetation changes on water yield and evapotranspiration. Journal of Hydrology 55(1-4):3-23.

Brooks, K.N., P.F. Ffolliot, and J.A. Magner. 2013. Hydrology and the Management of Watersheds, 4th ed. Oxford: John Wiley \& Sons.

Cerdà, A., and S.H. Doerr. 2005. Influence of vegetation recovery on soil hydrology and erodibility following fire: an 11-year investigation. International Journal of Wildland Fire 14(4):423-437.

Chu, T.W., and A. Shirmohammadi. 2004. Evaluation of the SWAT model's hydrology component in the piedmont physiographic region of Maryland. Transactions of the ASAE 47(4):1057.

Cooper, C.F. 1960. Changes in vegetation, structure, and growth of southwestern pine forests since white settlement. Ecological Monographs 30(2):129-164.

Cram, D.S., T.T. Baker, J. Boren, and C. Edminster. 2003. Inventory and classification of wildland fire effects in silvicultural treated vs. untreated forest stands of New Mexico and Arizona. Second International Wildland
Fire Ecology and Management Congress, Orlando, Florida, November 16-20, 2003.

Cram, D.S., T.T. Baker, A.G. Fernald, A. Madrid, and B. Rummer. 2007. Mechanical thinning impacts on runoff, infiltration, and sediment yield following fuel reduction treatments in a southwestern dry mixed conifer forest. Journal of Soil and Water Conservation 62(5):359-366.

Dodson, E.K., D.W. Peterson, and R.J. Harrod. 2008. Understory vegetation response to thinning and burning restoration treatments in dry conifer forests of the eastern Cascades, USA. Forest Ecology and Management 255(8-9):3130-3140.

Eslamian, S., ed. 2014. Handbook of Engineering Hydrology: Environmental Hydrology and Water Management. Boca Raton, FL: CRC Press.

Fernald, A.G., J. Gallegos, D.M.VanLeeuwen, and T.T. Baker. 2012. Evaluation of litter hydrology in ponderosa pine and mixed conifer stands in northern New Mexico, USA. New Mexico Academy of Science 4:121-136.

Furniss, M.J., B.P. Staab, S. Hazelhurst, C.F. Clifton, K.B. Roby, B.L. Ilhardt, E.B. Larry, A.H. Todd, L.M. Reid, S.J. Hines, K.A. Bennett, C.H. Luce, and P.J. Edwards. 2010. Water, Climate Change, and Forests: Watershed Stewardship for a Changing Climate. USDA, Forest Service, Pacific Northwest Research Station. https:// www.fs.fed.us/pnw/pubs/pnw_gtr812.pdf.

Garduno, H.R., A.G. Fernald, and D.M. VanLeeuwen. 2015. Non-commercial thinning effects on runoff and sediment yield in mixed conifer New Mexico forest. Journal of Soil and Water Conservation 70(1):12-22. https://doi.org/10.2489/jswc.70.1.12.

Goeking, S.A., J.D. Shaw, C. Witt, M.T. Thompson, C.E. Werstak Jr, M.C. Amacher, M. Stuever, T.A. Morgan, C.B. Sorenson, S.W. Hayes, and C.P. Mclver. 2014. New Mexico's Forest Resources, 2008-2012. Fort Collins, CO: United States Department of Agriculture, Forest Service, Rocky Mountain Research Station. https:// www.fs.usda.gov/treesearch/pubs/46050.

Grace, J.M., III. 2005. Application of WEPP to a southern Appalachian forest road. ASAE Paper No. 052016. St. Joseph, MI:American Society of Agricultural Engineers. Grace, J.M., III. R.W. Skaggs, and G.M. Chescheir. 2006. Hydrologic and water quality effects of thinning loblolly pine. Transactions of the ASABE 49(3):645-654.

Hibbert, A.R. 1965. Forest Treatment Effects on Water Yield. Asheville, NC: Coweeta Hydrologic Laboratory, Southeastern Forest Experiment Station.

Hicks, B.J., R.L. Beschta, and R.D. Harr. 1991. Long-term changes in streamflow following logging in western Oregon and associated fisheries implications. JAWRA: Journal of the American Water Resources Association 27(2):217-226.

Kuehl, R.O. 1994. Statistical Principles of Research Design and Analysis. Pacific Grove, CA: Duxbury Press.

Lal, R., and M.K. Shukla. 2004. Principles of Soil Physics. New York: Marcel Dekker Inc. 
Lane, P.N., and S.M. Mackay. 2001. Streamflow response of mixed-species eucalypt forests to patch cutting and thinning treatments. Forest Ecology and Management 143(1-3):131-142.

Lee, R. 1980. Forest Hydrology. New York: Columbia University Press.

Lemmon, P.E. 1956. A spherical densiometer for estimating forest overstory density. Forest Science 2(4):314-320.

Lesch,W., and D.F. Scott. 1997.The response in water yield to the thinning of Pinus radiata, Pinus patula and Eucalyptus grandis plantations. Forest Ecology and Management 99(3):295-307.

Luo, P., M. Zhou, H. Deng, J. Lyu,W. Cao, K.Takara, D. Nover, and S.G. Schladow. 2018. Impact of forest maintenance on water shortages: Hydrologic modeling and effects of climate change. Science of the Total Environment 615:1355-1363.

MacDonald, L.H., and J.D. Stednick. 2003. Forests and water: A state-of-the-art review for Colorado. Colorado Water Resources Research Institute Completion Report 196. Fort Collins, CO: Colorado State University.

Madrid, A., A.G. Fernald, T.T. Baker, and D.M.VanLeeuwen. 2006. Evaluation of silvicultural treatment effects on infiltration, runoff, sediment yield, and soil moisture in a mixed conifer New Mexico forest. Journal of Soil and Water Conservation 61(3):159-168.

Martin, D.A., and J.A. Moody. 2001. Comparison of soil infiltration rates in burned and unburned mountainous watersheds. Hydrological Processes 15(15):2893-2903.

Martínez-Murillo, J.F., E. Nadal-Romero, D. Regüés, A. Cerdà, and J. Poesen. 2013. Soil erosion and hydrology of the western Mediterranean badlands throughout rainfall simulation experiments: A review. Catena 106:101-112.

New Mexico State Universty. 2009. Upper Mora Watershed Collaborative Forest Restoration Program Technical Report . Unpublished paper.

NOAA/NCDC (National Oceanic and Atmospheric Administration, National Climatic Data Center). 2020. NOAA's National Climatic Data Center. https://www. ncei.noaa.gov/orders/cdo/2549009.pdf.

Oliver, W.W., and R.A. Ryker. 1990. Pinus ponderosa Dougl. Ex Laws: Ponderosa pine. In Silvics of North America, Volume 1, eds. R.M. Burns and B.H. Honkala, 413-424. Agriculture Handbook No. 654. Washington, DC: US Department of Agriculture Forest

Pannkuk, C.D., and P.R. Robichaud. 2003. Effectiveness of needle cast at reducing erosion after forest fires. Water Resources Research 39(12). https://doi. org/10.1029/2003WR002318.

Ramsey, F.L, and D.W. Schafer. 2002. The statistical sleuth: A course in methods of data analysis. Pacific Grove, CA: Duxbury Press.

Rice, R.M., F.B. Tilley, and P.A. Datzman. 1979. A watershed's response to logging and roads: South Fork of Caspar Creek, California, 1967-1976. Research Paper PSW-RP-146. Berkeley, CA: US Department of
Agriculture, Forest Service, Pacific Southwest Forest and Range Experiment Station.

Robichaud, P.R., J.L. Beyers, and D.G. Neary. 2000. Evaluating the effectiveness of postfire rehabilitation treatments. Fort Collins, CO: US Department of Agriculture, Forest Service, Rocky Mountain Research Station.

Robichaud,P.R.,J.L.Beyers, and D.G. Neary. 2005. Watershed rehabilitation. In Wildland Fire in Ecosystems: Effects of Fire on Soils and Water, eds. D.G. Neary, K.C. Ryan, and L.F. DeBano, 179-197. General Technical Report RMRS-GTR-42-vol.4. Ogden, UT: Rocky Mountain Research Station, USDA Forest Service.

Robles, M.D., and C. Enquist. 2010. Managing changing landscapes in the Southwestern United States. Tucson, AZ:The Nature Conservancy.

SAS Institute, Inc. 2013. SAS OnlineDoc 9.4. Cary, NC: SAS Institute Inc.

Schüler, G. 2006. Identification of flood-generating forest areas and forestry measures for water retention. Forest Snow and Landscape Research 80(1):99-114.

Sheridan, G.J., P.J. Noske, P.N.J. Lane, and C.B. Sherwin. 2008. Using rainfall simulation and site measurements to predict annual interrill erodibility and phosphorus generation rates from unsealed forest roads: Validation against in-situ erosion measurements. Catena 73(1):49-62.

Stednick, J.D. 1996. Monitoring the effects of timber harvest on annual water yield. Journal of Hydrology 176:79-95.

Stednick, J.D. 2000. Timber management. In Drinking Water from Forests and Grasslands: A Synthesis of the Scientific Literature, ed. G.E. Dissmeyer, 103-09. General Technical Report SRS-39. Asheville, NC: US Department of Agriculture Forest Service, Southern Research Station.

Stroup, W.W. 2012. Generalized linear mixed models: modern concepts, methods, and applications. Boca Raton FL: CRC Press.

Sun, G., S.G. McNulty, J. Lu, D.M. Amatya, Y. Liang, and R. K. Kolka. 2005. Regional annual water yield from forest lands and its response to potential deforestation across the southeastern United States. Journal of Hydrology 308(1-4):258-268.

Swetnam, T.W. 1990. Fire history and climate in the southwestern United States. In Proceedings of the symposium on effects of fire management of southwestern United States natural resources. General Technical Report RM-GTR-191. Fort Collins, CO: US Department of Agriculture, Forest Service, Rocky Mountain Forest and Range Experiment Station.

Swetnam, T.W., and C.H. Baisan. 2003. Tree-ring reconstructions of fire and climate history in the Sierra Nevada and southwestern United States. In Fire and Climatic Change in Temperate Ecosystems of the Western Americas, 158-195. New York, NY: Springer.

Swetnam, T.W., and J.L. Betancourt. 1990. Fire-southern oscillation relations in the southwestern United States. Science 249(4972):1017-1020.
Thomas, S.C., C.B. Halpern, D.A. Falk, D.A. Liguori, and K.A. Austin. 1999. Plant diversity in managed forests: Understory responses to thinning and fertilization. Ecological Applications 9(3):864-879.

Touchan, R., T.W. Swetnam, and H.D. Grissino-Mayer. 1995. Effects of livestock grazing on pre-settlement fire regimes in New Mexico. US Forest Service General Technical Report INT 320:268-272.

Triemble, S.W., and F.H. Weirich. 1987. Reforestation reduces streamflow in the southeastern United States. Journal of Soil and Water Conservation 42(4):274-276.

Troendle, C.A., and C.F. Leaf. 1980. Hydrology, An approach to water resources evaluation of non-point silvicultural sources. Vol. 12. EPA 60018-80. Washington, DC: US Environmental Protection Agency.

Vinge, T., and M. Pyper. 2012. Managing woody materials on industrial sites: Meeting economic, ecological and forest health goals through a collaborative approach. Edmonton, Alberta: Department of Renewable Resources, University of Alberta.

Weaver, H. 1964. Fire and management problems in ponderosa pine forests. Proceedings of the Annual Tall Timbers Fire Ecology Conference 3:60-79.

Wilcox, B.P., M.K. Wood, J.T. Tromble, and T.J.Ward. 1986.A hand-portable single nozzle rainfall simulator designed for use on steep slopes. Journal of Range Management 39(4):375-377.

Yanai, R.D., M.J. Twery, and S.L Stout. 1998. Woody understory response to changes in overstory density: Thinning in Allegheny hardwoods. Forest Ecology Management 102:45-60.

Yanosek, K.A., R.B. Foltz, and J.H. Dooley. 2006. Performance assessment of wood strand erosion control materials among varying slopes, soil textures, and cover amounts. Journal of Soil and Water Conservation 61(2):45-51.

Zemke,J.J. 2016. Runoff and soil erosion assessment on forest roads using a small scale rainfall simulator. Hydrology 3(3): 25 